IZA DP No. 7307

Contribution Games and the End-Game Effect: When Things Get Real - An Experimental Analysis

Ronen Bar-El

Yossef Tobol

March 2013 


\title{
Contribution Games and the End-Game Effect: When Things Get Real - An Experimental Analysis
}

\author{
Ronen Bar-El \\ Open University of Israel \\ Yossef Tobol \\ Jerusalem College of Technology, \\ Carmel Academic Center and IZA \\ Discussion Paper No. 7307 \\ March 2013 \\ IZA \\ P.O. Box 7240 \\ 53072 Bonn \\ Germany \\ Phone: +49-228-3894-0 \\ Fax: +49-228-3894-180 \\ E-mail: iza@iza.org
}

\begin{abstract}
Any opinions expressed here are those of the author(s) and not those of IZA. Research published in this series may include views on policy, but the institute itself takes no institutional policy positions. The IZA research network is committed to the IZA Guiding Principles of Research Integrity.

The Institute for the Study of Labor (IZA) in Bonn is a local and virtual international research center and a place of communication between science, politics and business. IZA is an independent nonprofit organization supported by Deutsche Post Foundation. The center is associated with the University of Bonn and offers a stimulating research environment through its international network, workshops and conferences, data service, project support, research visits and doctoral program. IZA engages in (i) original and internationally competitive research in all fields of labor economics, (ii) development of policy concepts, and (iii) dissemination of research results and concepts to the interested public.
\end{abstract}

IZA Discussion Papers often represent preliminary work and are circulated to encourage discussion. Citation of such a paper should account for its provisional character. A revised version may be available directly from the author. 
IZA Discussion Paper No. 7307

March 2013

\section{ABSTRACT}

\section{Contribution Games and the End-Game Effect: When Things Get Real - An Experimental Analysis ${ }^{1}$}

We conduct a contribution game for a real public good and show that when the contributors value the real public good highly, they increase their contributions in each round. Thus, contrary to previous literature, free riding decreases over rounds and the end-game effect is reversed.

JEL Classification: $\quad$ C72, C92, H41

Keywords: $\quad$ public goods experiment, end-game effect, free-riding

Corresponding author:

Yossef Tobol

Jerusalem College of Technology

21 Havaad Haleumi

P.O.B. 16031

91160 Jerusalem

Israel

E-mail: Toboly@gmail.com

\footnotetext{
${ }^{1}$ We are grateful to Bradley Ruffle, Eran Menes, Amrish Patel, Leonid Azarnert, Alon Cohen, Iael BarEl and Michal Tobol for their most helpful comments.
} 


\section{Introduction}

Many repeated linear public goods laboratory experiments showed that backwards induction-based contributions are substantially more generous than expected zero Nash equilibrium contributions. ${ }^{2}$ However, these experiments showed that individuals interacting in a finite rounds contribution game often start out by contributing substantial amounts that decline as the number of rounds increases, and reach their minimum towards the end of the game. This is called the "end-game effect" (see Andreoni 1988). The end-game effect remains valid even if we deviate from the commonly known and symmetric endpoint assumption ${ }^{3}$, or when contributions are made in a sequence that is randomized at each round instead of simultaneously ${ }^{4}$ The common experiment protocol usually follows Isaac et al. (1984); that is, each participant is given an amount of ECU (Experimental Currency Units), and each privately decides how to divide the ECU between themselves and the public good, where one ECU contributed to finance the public good adds less than one ECU to the reward. That is, the contributions finance an "imaginary" public good, e.g. a public good that has no value of its own. Nevertheless, in real life people contribute to public goods which they value and this inclination may change their contributions path in a repeated contribution game.

To examine whether preference towards the public good affects the contribution path, we conducted the following contribution game experiment. The participants in the experiment, who were all Jews, were divided into four

\footnotetext{
${ }^{2}$ See Ledyard (1995) and Chaudhui (2011) for survey of public goods experimental research. See also Wilhelm, Brown, Rooney and Steinberg (2008) for empirical evidence on intergenerational transmission generosity.

${ }^{3}$ See Gonzalez, Guth and Levati (2005).

${ }^{4}$ See Figuires, Masclet and Willinger (2012).
} 
groups according to their religious orientation - ultra-Orthodox, Orthodox, traditional or secular - and were asked to contribute to a real public good the establishment of a new synagogue. This public good differentiates preferences between the four groups; as the degree of religiosity of an individual increases so does his preference toward the establishment of a synagogue, since a religious individual uses synagogues daily and therefore values them highly while a secular individual rarely uses them and therefore is not expected to have a strong preference toward the establishment of a new synagogue.

Our results show that the value of the public good in the eye of the contributors may cause the participants to deviate from previously observed common behavior. Accordingly, free riding decreases over rounds and the endgame effect vanishes among the ultra-Orthodox and Orthodox groups, the groups who have a strong preference for the public good, while it remains valid among the groups of the traditional and secular, i.e., the groups that do

not have strong preference for a synagogue. Our paper suggests that the extent of free riding and the end-game effect may well depend upon the degree of preference for the public good among the groups of contributors.

\section{Experimental design and procedures}

The computerized experiments took place between the $9^{\text {th }}$ of December 2012 and the $3^{\text {th }}$ of January 2013. The participants in the experiment were undergraduate students from different disciplines at the Jerusalem and BneiBrak campuses of the Jerusalem College of Technology, whose students are mainly ultra-Orthodox and Orthodox Jews, and from the Carmel academic center in Haifa, whose students are mainly secular and traditional Jews. Each 
of the participants was given 500 ECU where each 50 ECU represents 5 ILS (about 1 EUR or $\$ 1.35$ ). After self-classifying themselves into one of the four groups, each was asked to donate privately to one of two known fellowships which build synagogues around Israel, one related to the ultra-Orthodox denomination and the other to the (Zionist) Orthodox denomination.

Two versions of the experiment were conducted. The first version involved 108 participants (27 in each group) who were asked to contribute privately to a fellowship in one round. The second version of the experiment, involving 140 participants, was a five rounds contribution game. In any one round each participant (35 in each group) was endowed with 100 ECU. After being seated at a computer terminal the participants received written instructions. Understanding of the rules was ensured by a control questionnaire that subjects had to answer before the experiment started. ${ }^{5}$

The donations to the fellowships were cashed and transferred to their representatives and the rest was cashed by the participants.

\footnotetext{
${ }^{5}$ Instructions and control questionnaire are available from the authors upon request.
} 


\section{Experimental results}

\subsection{The one round contribution game}

Figure 1 displays the average contributions of the four groups in the one round contribution game.

\section{Figure 1}

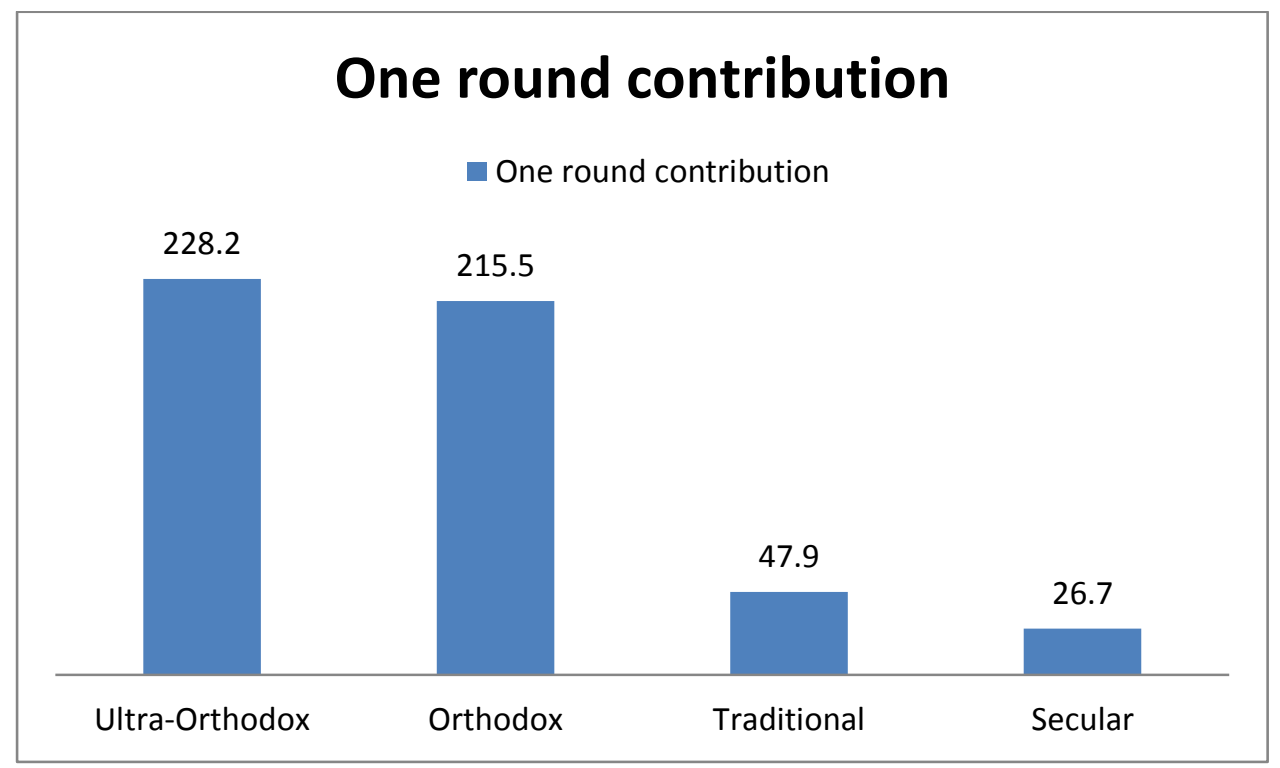

Figure 1 shows that the ultra-Orthodox Jews contributed on average 228.2 ECU to the fellowship, the Orthodox 215.5, the traditional 47.9 and the secular Jews contributed 26.7 ECU. We conducted t-tests and found that the differences in the average contributions between the following groups: ultraOrthodox and secular, ultra-Orthodox and traditional, Orthodox and secular, Orthodox and traditional - are statistically significant at a significance level of less than $1 \% .^{6}$ The difference in the average contribution between the secular

\footnotetext{
${ }^{6}$ The differences were also found to be statistically significant when we ran difference in differences regressions with significance level of less than $1 \%$.
} 
and traditional is statistically significant at a significance level of $10 \%$. The difference in the average contribution between the ultra-Orthodox and Orthodox was not found to be statistically significant. In addition, the hypothesis that the average contributions in figure 1 were drawn from a uniform distribution was rejected in a $\chi^{2}(3)$ test.

\subsection{The five rounds contribution game and the end-game effect.}

Figure 2 shows the evolution of the average contributions in the five rounds contribution game.

\section{Figure 2}

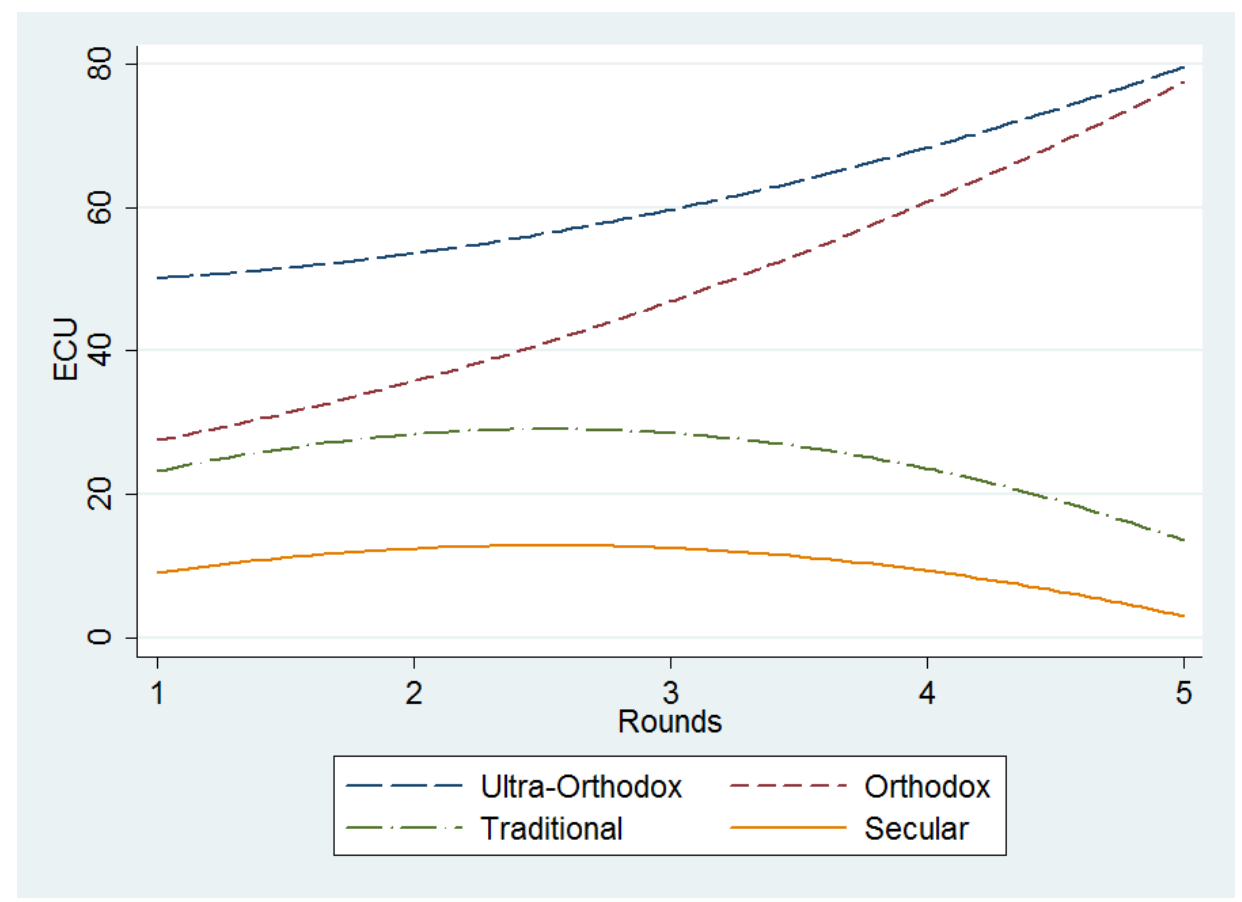

We see that the contribution path of the ultra-Orthodox and Orthodox is upward sloping while that of the traditional and secular is downward sloping. 
We conducted t-tests to compare the average contribution in the first four rounds with that of the last round and discovered that the contributions of the ultra-Orthodox and Orthodox in the last round are statistically significantly higher than their average contribution in the first four rounds at a less than $1 \%$ significance level, while those of the traditional and secular are statistically significantly lower at a less than $1 \%$ significance level. $^{7}$

\section{Summary and Discussion}

Our experiments reveal that the extent of free riding and the existence of the end-game effect may well depend upon the value of the public good to the group of contributors. Accordingly, we have seen that with respect to contributions to the establishment of a synagogue, free riding is mitigated and the end-game effect does not exist among the groups of Orthodox and ultraOrthodox Jewish contributors, who value the public good highly, while free riding is significant and the end-game effect exists among the groups of traditional and secular Jewish contributors who do not have a strong preference toward the public good and whose contribution behavior is therefore consistent with previous experiments. Moreover, we found that the contribution path of the Orthodox and ultra-Orthodox is higher than that of the traditional and secular Jews.

The degree of religiosity serves in this paper as a distinction between individuals with respect to their preferences. As it turned out in our experiments, differences in preferences induce differences in the contributions to public goods. It would be of great interest to further identify the role of preferences in shaping economic behavior.

\footnotetext{
${ }^{7}$ We verified our conclusions by comparing the average contributions in the first three rounds with those of the last two rounds and also by running difference in differences regressions.
} 


\section{References}

Andereoni, J. (1988). Why free ride? Strategies and learning in public good experiments. Journal of Public Economics 37(3), 291-304.

Brown, E., Rooney, P., Steinberg, R., Wilhelm, M. (2008). The

Intergenerational Transmission of Generosity. Journal of Public Economics 92(10-11), 2146-2156.

Chaudhui, A. (2011). Sustaining cooperation in laboratory public goods experiments: a selective survey of the literature. Experimental Economics 14(1), 47-83.

Figuires, C., Masclet, D Willinger, M. (2012). Vanishing Leadership and Declining Reciprocity in a Sequential Contribution Experiment. Economic Inquiry 50(3), 567-584.

Gonzales, L.G., Guth, W.M., Levati, V. (2005). When does the game end? Public goods experiments with non-definite and non-commonly known time horizons. Economics Letters 88(2), 221-226.

Isaac, R.M., Walker, J. and Thomas, S.H. (1984). Divergent evidence on free riding: an experimental examination of possible explanations, Public Choice 41(1), 113-149.

Ledyard, J.O., (1995). Public goods: a survey of experimental research. In Kagel, J., Roth, A.E. (Eds.), Handbook of Experimental Economics (pp. 111194). Princeton University Press, Princeton, New Jersey. 